\title{
NATURAL AND HUMAN IMPACTS ON INVERTEBRATE COMMUNITIES IN BRAZILIAN CAVES
}

\author{
FERREIRA, R. L. ${ }^{1,2}$ and HORTA, L. C. S. ${ }^{2}$ \\ ${ }^{1}$ Laboratório de Ecologia e Comportamento de Insetos, Departamento de Biologia Geral, UFMG, C.P. 486, \\ CEP 30161-970, Belo Horizonte, MG, Brazil \\ ${ }^{2}$ Grupo Bambuí de Pesquisas Espeleológicas \\ Correspondence to: Rodrigo Lopes Ferreira, Laboratório de Ecologia e Comportamento de Insetos, Departamento \\ de Biologia Geral, UFMG, C.P. 486, CEP 30161-970, Belo Horizonte, MG, Brazil, e-mail: drops@icb.ufmg.br \\ Received June 22, 1999 - Accepted April 13, 2000 - Distributed February 28, 2001
}

\begin{abstract}
Species richness, abundance, distribution and similairity between cave invertebrate communities were compared among seven caves located in the Peruaçu River valley, north of Minas Gerais State, Brazil. Such comparisons aimed to determinate the degree of biological complexity in the sampled caves, calculated by the "Index of Biological Complexity in Caves", presented in this manuscript. The presence of potencial or real impacts on the cave fauna was also investigated. A total of 1,468 individuals belonging to 57 families of: Acarina, Pseudoscorpionida, Araneida, Opilionida, Amblypygi, Isopoda, Geophilomorpha, Scutigeromorpha, Spirostreptida, Coleoptera, Collembola, Diptera, Dictyoptera, Ephemeroptera, Ensifera, Heteroptera, Hymenoptera, Lepidoptera, Plecoptera, Psocoptera, and Trichoptera was collected. Caves with higher resource availability (as those hidrologicaly actives) had a higher biological complexity than those with less resource. There are two types of impacts that occur in the area: the natural (geological) and the anthropic, as intense "stepping" and visitation or use of cave entrances as cattle shelters. There are caves with different preservation degrees in the area, with invertebrate communities in varied complexity states. The communities of these caves undoubtedly deserve care, since the area is extremely important in the Brazilian biospeleological context.
\end{abstract}

Key words: caves, communities, impacts, invertebrates, Peruaçu River.

\section{RESUMO}

\section{Impactos sobre Comunidades de Invertebrados em Cavernas Brasileiras}

Comparou-se a composição, a riqueza, a abundância, a distribuição e a similaridade entre as comunidades de artrópodes cavernícolas presentes em sete cavernas situadas no vale do Rio Peruaçu, norte do Estado de Minas Gerais. Tal comparação visou à determinação do grau de complexidade biológica das cavernas da região, que foi estimada pelo "Índice de complexidade biológica em cavernas" apresentado neste trabalho. Foi avaliada, também, a existência de impactos reais ou potenciais sobre a fauna cavernícola. Foram coletados 1.468 indivíduos pertencentes a 57 famílias de: Acarina, Pseudoscorpionida, Araneida, Opilionida, Amblypygi, Isopoda, Geophilomorpha, Scutigeromorpha, Spirostreptida, Coleoptera, Collembola, Diptera, Dictyoptera, Ephemeroptera, Ensifera, Heteroptera, Hymenoptera, Lepidoptera, Plecoptera, Psocoptera e Trichoptera. Cavernas com maior disponibilidade de recursos (percorridas pelo Rio Peruaçu) tiveram maior complexidade biológica do que aquelas com menor quantidade de recursos. Dentre os impactos existentes na área, destacam-se os de origem natural (geológica) e os de origem antrópica, como pisoteamento, elevada visitação e utilização de entradas das cavernas para a pecuária. As cavernas da região mostram-se de extrema importância dentro do panorama bioespeleológico nacional (tanto pela riqueza de espécies quanto pela coexistência de grupos epígeos e hipógeos), merecendo especial proteção.

Palavras-chave: cavernas, comunidades, impactos, invertebrados, Rio Peruaçu. 


\section{INTRODUCTION}

Caves are considered stable environments when compared with epigean habitats and are also characterized by a permanent lack of light far from entrances (Poulson \& White, 1969; Culver, 1982). In the absence of photoautotrophic organisms, heterotrophs should find other sources of resources that usually are scarce. These resources are mainly organic matter imported to caves by water, gravity, or animal excreta or their dead bodies. In some dry caves, the main resource is guano of bats, birds or crickets wich can form large piles (Herrera, 1995; Ferreira, 1998).

The cave organisms can be classified in three categories (Holsinger \& Culver, 1988, based on Schinner-Racovitza's system): 1. The trogloxens are often found in caves, but they leave it regularly to feed. They generally occur close to the entrances, but eventually great populations can be found places far from the entrances. So, many of these organisms import energy from the epigean system, being, many times, the main responsible for the energy flow in cave systems, as permanently dry caves. 2. The troglophiles are capable of completing their life cycle inside or outside caves. Some species can, still, be trogloxens under certain circumstances and troglophiles in others (e.g. caves with aboundant organic matter). 3. The troglobites are restricted to caves, mainly due to the specializations they acquired during genetic isolation, by alopatry or not. Such specializations (morphologic - e.g. reduction of the ocular structures and lack of pigments - physiologic or behavioral) probably evolved in response to the selective pressures found in caves or by the absence of typical selective pressures found in epigean environments.

Caves are important for the ecosystem balance in their occurrence areas. The interferences in the physical environment caused by human actions or natural phenomenons are directly reflected in caves located in areas in which these impacts can occur. The alteration of the original structure of a cave system caused by different impacts can disturb the external system, stressing the state of unbalance of a given ecosystem (Lisowski \& Poulson, 1981; Lewis, 1982; Elliot, 1981).

Environmental impacts can result from natural or human activities, that produce abrupt alterations in parts of the environment or in the environment as a whole. Caves experienced, in their geological evolution, moments of permanent darkness and high environmental stability, if compared to external systems.

However, the environmental situation of each cave depends on the type and the period of its geological evolution, and different cave systems certainly are characterized by distinct environmental conditions (influenced by the local and regional external climatic regime).

So, any event that modifies the presumably "original" situation of a cave (permanent darkness and high environmental stability), independent of the time since it occurred, can result in impact. Situations that modify a cave system relatively fast can cause disturbances to which many organisms are not adapted, resulting in the local extinction of many taxa. Hence, the time since an impact occurred, although being important for the evolution of groups or biological systems in caves, is probably less important than the intensity of the alterations this impact caused in a cave system. It is very difficult to estimate the time elapsed since the occurence of an event that caused a disturbance in a cave. So, the monitoration of some cave variables (environmental, trophic and zoological) and the comparison of these same variables measured in different caves, can indicate the conservation degree of a cave system, even if these are not the most adequate "tools" for this type of study.

The classification of a cave system as "conserved" or "disturbed" depends, therefore, on a very complete characterization of the cave ecosystem and its surroundings, taking into account several factors, as climate, drainages, alimentary resources, fauna, and anthropic actions.

The conservation of cave ecosystems is very important for the maintenance of the ecological relationships specific of these environments, and also for the maintenance of the external ecosystems.

The aims of this study were:

1. Characterize the caves regarding species richness (emphasis in invertebrates).

2. Detect possible situations of diferential species distribution in the caves.

3. Compare species compositions among different caves.

4. Evaluate the existence and effects of possible impacts on the cave fauna in the area. 


\section{METHODOLOGY}

\section{Study area}

The Peruaçu valley river is located in the north of Minas Gerais State, between the contries Januária and Itacarambi, approximately $650 \mathrm{~km}$ of Belo Horizonte. Because of the high amount of speleological and archaeological sites of cientific and cultural importance, the area was considered an Environmental Protection Area by the law n. 98182 , of september 26 of 1989 . The area is located in the transition of two phytogeografic types: cerrado and caatinga (IBGE, 1993). In this transition, several sub-types of vegetation, in different degrees of conservation, can be distinguished.
In the choice of the caves, those visited periodically were given preference. It was assumed that this constant visitation could be causing some modifications in the communities of these caves. Some caves that are not periodically visited were also included so comparisons among the systems could be made (Table 1). According to Piló (1997), the caves of the area can be divided in two main groups: the hydrologically active caves, directly related to the Peruaçu River (Brejal and Janelão) and the dry caves, positioned above the phreatic level. The dry caves are located in smaller canyons perpendicular to the course of the Peruaçu river (Caboclo, Bonita), in residual outcrops or even in outcrops of the main canyon (Carlúcio, Rezar and Ossos).

TABLE 1

Caves sampled in the study. Marked* caves are hydrologically actives.

\begin{tabular}{|l|c|c|c|}
\hline \multicolumn{1}{|c|}{ Cave } & City & Coordenates & $\begin{array}{c}\text { Horizontal } \\
\text { development (m) }\end{array}$ \\
\hline Ossos & Itacarambi & - & - \\
\hline Bonita & Itacarambi & $44^{\circ} 14^{\prime} 20^{\prime \prime} \mathrm{W} 15^{\circ} 06^{\prime} 23^{\prime \prime} \mathrm{S}$ & 420 \\
\hline Caboclo & Itacarambi & $43^{\circ} 51^{\prime} 24^{\prime \prime} \mathrm{W} 18^{\circ} 17^{\prime} 14^{\prime \prime} \mathrm{S}$ & 120 \\
\hline Carlúcio & Januária & $44^{\circ} 15^{\prime} 43^{\prime \prime} \mathrm{W} 15^{\circ} 05^{\prime} 01^{\prime \prime} \mathrm{S}$ & - \\
\hline Rezar & Januária & $44^{\circ} 13^{\prime} 06^{\prime \prime} \mathrm{W} 15^{\circ} 08^{\prime} 28^{\prime \prime} \mathrm{S}$ & 380 \\
\hline Janelão* & Januária/Itacarambi & $44^{\circ} 14^{\prime} 27^{\prime \prime} \mathrm{W} 15^{\circ} 06^{\prime} 54^{\prime \prime} \mathrm{S}$ & 4,740 \\
\hline Brejal* & Januária/Itacarambi & $44^{\circ} 15^{\prime} 39^{\prime \prime} \mathrm{W} 15^{\circ} 05^{\prime} 07^{\prime} \mathrm{S}$ & 1,420 \\
\hline
\end{tabular}

\section{METHODS}

The comparisons among the communities were made based in non-replicable data, since each cave have specific situations of communities' organization and environment. The present work considered mainly invertebrates, since they are responsible for the greatest part of the total richness and diversity of almost every cave system.

The collections of organisms were done in four visits to the study area, in the months of December 1997, July 1998, and September 1998. The collection of terrestrial invertebrates was made by manual capture (with the aid of tweezers, brushes and entomological nets). During these collections, the approached size of each morphospecies popu- lation was observed (Reduced: less than 20 individuals; Medium: 20 to 50 individuals; Large: more than 50 individuals) as well as the substrata on which each population was found. The invertebrates were still sampled with pitfall traps, with formalin $(5 \%)$ and liver baits. The pitfalls were placed in 20 meters intervals in four of the sampled caves (Ossos, Caboclo, Carlúcio, and Bonita - eight traps in each) and in 40 meters intervals in three caves (Janelão - 14 traps, Brejal - 11 traps, Rezar 8 traps). Each traps series was left for three days in each cave. The different distances between each trap among the caves can be justified by the different sizes of caves.

The similarity among cave communities was calculated using the Sorensen index (Wolda, 1981). 
The invertebrate communities' diversity was not calculated, since the abundance of the different populations were not sufficiently precise for the determination of this index for the communities.

The degree of biological complexity was obtained comparing the cave richness with the percentages of relative abundances of each invertebrate population, through an index explained below.

It is important to stand out that this index is extremely restricted, since it only considers two parameters, one of them of qualitative nature. Richer caves with populations (Reduced, Medium and Large) more homogeneously distributed (high equitability) were considered more "complex" from the biological point of view than those less rich and with species with great disparity in population sizes or low equitability (e.g. a lot of species with reduced populations and few with medium and big populations), since communities with high equitability have a larger potential conectance than those with great disparities in population sizes. In this analysis, however, groups that are not very common or "accidental" in caves (e.g. Hesperiidae, Heliconiidae, Vespidae, Pompilidae, Ptinidae, Anobiidae) were not considered, since they were found in some caves probably due to their environmental conditions very similar to the external (e.g. skylights in Janelão).

Ants were excluded from the analyses in which data of population sizes were necessary, since in cases of colonial organisms it is generally considered the colony as an individual. The determination of how many colonies were involved in the individuals' abundance found was impossible in this work.

The complexity was estimated through the "Index of Biological Complexity in Caves" (IBCC), calculated in the following way: it was determined, initially, the percentage of morphospecies present in each populational group (Small populations, Medium populations and Large populations). The gap among each percentage was then calculated; so that 2 values of numeric distances were found among the 3 groups of population percentages in each cave. It was calculated, then, the average of these distances or, in other words, the average width among the populational percentages. The average width was, then, multiplied by 100 and divided by the maximum populational percentage of each cave. The square of the richness of each cave was then divided by the number obtained in this calculation, called relative populational width. The value obtained in this division is the IBCC. The square of the richness was used to give a larger weight to this parameter, that, besides being of quantitative nature, has great importance in the complexity of any biological system.

Impacts were looked for through observations of different situations or human activity near the cave entrances $(\sim 250 \mathrm{~m})$ and inside each cave.

\section{RESULTS}

A total of 1,468 individuals belonging to 57 families of: Acarina, Pseudoscorpionida, Araneida, Opilionida, Amblypygi, Isopoda, Geophilomorpha, Scutigeromorpha, Spirostreptida, Coleoptera, Collembola, Diptera, Dictyoptera, Ephemeroptera, Ensifera, Heteroptera, Hymenoptera, Lepidoptera, Plecoptera, Psocoptera, and Trichoptera was collected (Table 2). The orders Diptera (10 families) and Coleoptera ( 9 families) were those with the higher number of families; the others have just been represented by a maximum of 4 families. The species richness was variable, being higher in the caves transposed by the Peruaçu River (Brejal - 39 species, and Janelão - 36 species) than in the dry ones (Caboclo - 21 species, Carlúcio - 19 species, Ossos 17 species, Rezar - 17 species, and Bonita - 16 species). The populations' distribution of the different morphospecies inside each cave was variable. Some populations had a restricted distribution (e.g. guano deposits) while other were more widespread inside caves (e.g. Loxosceles sp.).

The caves presented similarity coefficients varying from 0.130 to 1.11 (Table 3 ). Some genus (e.g. Loxosceles sp. and Endecous sp.) had a widespread distribution, being present in all the studied caves (Table 4).

The index of biological complexity in caves (IBCC) was very variable among caves, showing values between 4.41 and 28.61 (Table 5). As expected, caves with rivers as Brejal and Janelão presented larger values for this index, as well as higher species richnesses. 
TABLE 2

Taxa reported in the sampled caves.

\begin{tabular}{|c|c|c|c|c|c|c|c|}
\hline \multirow[b]{2}{*}{ Taxa } & \multicolumn{7}{|c|}{ Cave } \\
\hline & $\begin{array}{c}\text { Brejal } \\
\text { Species } \\
\text { richness }\end{array}$ & $\begin{array}{c}\text { Janelão } \\
\text { Species } \\
\text { richness }\end{array}$ & $\begin{array}{c}\text { Carlúcio } \\
\text { Species } \\
\text { richness }\end{array}$ & $\begin{array}{l}\text { Caboclo } \\
\text { Species } \\
\text { richness }\end{array}$ & $\begin{array}{c}\text { Bonita } \\
\text { Species } \\
\text { richness }\end{array}$ & $\begin{array}{c}\text { Ossos } \\
\text { Species } \\
\text { richness }\end{array}$ & $\begin{array}{c}\text { Rezar } \\
\text { Species } \\
\text { richness }\end{array}$ \\
\hline \multicolumn{8}{|l|}{ - ARTHROPODA } \\
\hline \multicolumn{8}{|l|}{ - ARACHNIDA } \\
\hline - Acarina & 1 & 2 & 1 & 1 & $\mathbf{0}$ & 1 & 3 \\
\hline Cryptostigmata & 0 & 0 & 0 & 0 & 0 & 0 & 1 \\
\hline Metastigmata & 1 & 2 & 1 & 1 & 0 & 1 & 1 \\
\hline Bdellidae (?) & 0 & 0 & 0 & 0 & 0 & 0 & 1 \\
\hline - Pseudoscorpionida & $\mathbf{0}$ & 2 & 1 & 1 & $\mathbf{0}$ & 1 & 1 \\
\hline Garypidae & 0 & 1 & 1 & 0 & 0 & 1 & 1 \\
\hline Geogarypidae (?) & 0 & 1 & 0 & 0 & 0 & 0 & 0 \\
\hline Chernetidae & 0 & 0 & 0 & 1 & 0 & 0 & 0 \\
\hline - Araneida & 6 & 7 & 1 & 4 & 3 & 2 & 1 \\
\hline Theridiidae & 1 & 2 & 0 & 1 & 0 & 1 & 0 \\
\hline Sicariidae & 1 & 1 & 1 & 1 & 1 & 1 & 1 \\
\hline Pholcidae & 1 & 3 & 0 & 0 & 0 & 0 & 0 \\
\hline Ctenidae & 0 & 0 & 0 & 0 & 1 & 0 & 0 \\
\hline Family unident & 3 & 1 & 0 & 2 & 1 & 0 & 0 \\
\hline - Amblypygi & $\mathbf{0}$ & 1 & 1 & 1 & 0 & 1 & 1 \\
\hline Damonidae & 0 & 1 & 1 & 1 & 0 & 1 & 1 \\
\hline - Opilionida & 1 & $\mathbf{0}$ & 0 & $\mathbf{0}$ & 1 & 0 & 0 \\
\hline Gonyleptidae & 1 & 0 & 0 & 0 & 1 & 0 & 0 \\
\hline \multicolumn{8}{|l|}{ - CRUSTACEA } \\
\hline - Isopoda & 2 & 1 & $\mathbf{0}$ & $\mathbf{0}$ & 0 & 0 & 1 \\
\hline Armadillidae & 1 & 1 & 0 & 0 & 0 & 0 & 1 \\
\hline Dubioniscidae & 1 & 0 & 0 & 0 & 0 & 0 & 0 \\
\hline \multicolumn{8}{|l|}{ - MYRIAPODA } \\
\hline - Diplopoda & $\mathbf{0}$ & 2 & $\mathbf{0}$ & $\mathbf{0}$ & $\mathbf{0}$ & 0 & $\mathbf{0}$ \\
\hline Spirostreptida & 0 & 2 & 0 & 0 & 0 & 0 & 0 \\
\hline - Chilopoda & 2 & 1 & $\mathbf{0}$ & 1 & $\mathbf{0}$ & $\mathbf{0}$ & $\mathbf{0}$ \\
\hline Scutigeromorpha & 1 & 1 & 0 & 0 & 0 & 0 & 0 \\
\hline Scolopendromorpha & 0 & 0 & 0 & 1 & 0 & 0 & 0 \\
\hline Geophilomorpha & 1 & 0 & 0 & 0 & 0 & 0 & 0 \\
\hline \multicolumn{8}{|l|}{ - INSECTA } \\
\hline - Coleoptera & 5 & 5 & 5 & 4 & 2 & 2 & 2 \\
\hline Scarabaeidae & 0 & 1 & 0 & 1 & 0 & 0 & 0 \\
\hline Carabidae & 1 & 4 & 0 & 0 & 0 & 0 & 0 \\
\hline Tenebrionidae & 1 & 0 & 1 & 1 & 1 & 1 & 1 \\
\hline Ptinidae & 1 & 0 & 1 & 0 & 0 & 0 & 1 \\
\hline
\end{tabular}


TABLE 2 (Continuation).

\begin{tabular}{|c|c|c|c|c|c|c|c|}
\hline \multirow[b]{2}{*}{ Taxa } & \multicolumn{7}{|c|}{ Cave } \\
\hline & $\begin{array}{c}\text { Brejal } \\
\text { Species } \\
\text { richness }\end{array}$ & $\begin{array}{c}\text { Janelão } \\
\text { Species } \\
\text { richness }\end{array}$ & $\begin{array}{c}\text { Carlúcio } \\
\text { Species } \\
\text { richness }\end{array}$ & $\begin{array}{l}\text { Caboclo } \\
\text { Species } \\
\text { richness }\end{array}$ & $\begin{array}{c}\text { Bonita } \\
\text { Species } \\
\text { richness }\end{array}$ & $\begin{array}{c}\text { Ossos } \\
\text { Species } \\
\text { richness }\end{array}$ & $\begin{array}{c}\text { Rezar } \\
\text { Species } \\
\text { richness }\end{array}$ \\
\hline Staphylinidae & 1 & 0 & 0 & 0 & 1 & 0 & 0 \\
\hline Lampyridae & 1 & 0 & 0 & 0 & 0 & 0 & 0 \\
\hline Dermestidae & 0 & 0 & 1 & 1 & 0 & 1 & 0 \\
\hline Anobiidae & 0 & 0 & 0 & 1 & 0 & 0 & 0 \\
\hline Chrysomelidae & 0 & 0 & 1 & 0 & 0 & 0 & 0 \\
\hline Elateridae & 0 & 0 & 1 & 0 & 0 & 0 & 0 \\
\hline - Diptera & 12 & 10 & 1 & 2 & 4 & 2 & 2 \\
\hline Cyclorrhapha & 0 & 0 & 0 & 0 & 0 & 0 & 2 \\
\hline Drosophilidae & 4 & 2 & 0 & 0 & 1 & 0 & 0 \\
\hline Cecidomyiidae & 1 & 1 & 0 & 0 & 0 & 0 & 0 \\
\hline Chironomidae & 2 & 4 & 0 & 0 & 0 & 0 & 0 \\
\hline Simuliidae & 0 & 3 & 0 & 0 & 0 & 0 & 0 \\
\hline Phoridae & 4 & 0 & 0 & 0 & 2 & 0 & 0 \\
\hline Ceratopogonidae & 1 & 0 & 0 & 0 & 0 & 0 & 0 \\
\hline Tabanidae & 0 & 0 & 0 & 1 & 0 & 0 & 0 \\
\hline Psychodidae & 0 & 0 & 1 & 1 & 0 & 1 & 0 \\
\hline Tachinidae & 0 & 0 & 0 & 0 & 1 & 0 & 0 \\
\hline Family unident & 0 & 0 & 0 & 0 & 0 & 1 & 0 \\
\hline - Dictyoptera & 1 & 1 & 2 & $\mathbf{0}$ & 1 & $\mathbf{0}$ & $\mathbf{0}$ \\
\hline Blattidae & 1 & 1 & 2 & 0 & 1 & 0 & 0 \\
\hline - Ensifera & 1 & 1 & 1 & 1 & 1 & 1 & 1 \\
\hline Phalangopsidae & 1 & 1 & 1 & 1 & 1 & 1 & 1 \\
\hline - Heteroptera & 1 & 1 & 1 & 1 & $\mathbf{0}$ & 1 & 1 \\
\hline Reduviidae & 1 & 1 & 1 & 1 & 0 & 1 & 1 \\
\hline - Hymenoptera & 1 & 1 & 2 & 2 & 1 & 1 & 1 \\
\hline Formicidae & 1 & 1 & 2 & 0 & 1 & 0 & 0 \\
\hline Vespidae & 0 & 0 & 0 & 1 & 0 & 1 & 0 \\
\hline Pompilidae & 0 & 0 & 0 & 1 & 0 & 0 & 0 \\
\hline Apidae & 0 & 0 & 0 & 0 & 0 & 0 & 1 \\
\hline - Lepidoptera & 3 & 1 & 2 & 2 & 2 & 2 & 2 \\
\hline Tineidae & 2 & 1 & 2 & 1 & 2 & 2 & 1 \\
\hline Noctuidae & 0 & 0 & 0 & 1 & 0 & 0 & 0 \\
\hline Hesperiidae & 1 & 0 & 0 & 0 & 0 & 0 & 0 \\
\hline Heliconiidae & 0 & 0 & 0 & 0 & 0 & 0 & 1 \\
\hline - Plecoptera & 0 & 1 & 0 & 0 & 0 & 0 & 0 \\
\hline - Psocoptera & 1 & 0 & 1 & 1 & 1 & 3 & 1 \\
\hline Trogiidae & 1 & 0 & 1 & 1 & 1 & 2 & 1 \\
\hline Psyllipsocidae & 0 & 0 & 0 & 0 & 0 & 1 & 0 \\
\hline - Trichoptera & 0 & 1 & $\mathbf{0}$ & $\mathbf{0}$ & $\mathbf{0}$ & $\mathbf{0}$ & 0 \\
\hline
\end{tabular}


TABLE 3

Similarity matrix (Sorensen) among the invertebrate communities of the sampled caves.

\begin{tabular}{|c|c|c|c|c|c|c|c|}
\hline & Janelão & Brejal & Ossos & Carlúcio & Caboclo & Rezar & Bonita \\
\hline Janelão & $X$ & 0.423 & 0.233 & 0.222 & 0.163 & 0.293 & 0.130 \\
\hline Brejal & & $X$ & 0.281 & 0.381 & 0.304 & 0.213 & 0.333 \\
\hline Ossos & & & $X$ & 0.636 & 1.111 & 0.417 & 0.222 \\
\hline Carlúcio & & & & $\mathrm{X}$ & 0.538 & 0.400 & 0.417 \\
\hline Caboclo & & & & & $X$ & 0.357 & 0.276 \\
\hline Rezar & & & & & & $X$ & 0.320 \\
\hline Bonita & & & & & & & $X$ \\
\hline
\end{tabular}

TABLE 4

Occurrence matrix of the most common species in the caves of the area.

\begin{tabular}{|l|c|c|c|c|c|c|c|}
\hline \multicolumn{1}{|c|}{ Taxa } & Carlúcio & Ossos & Rezar & Brejal & Janelão & Caboclo & Bonita \\
\hline Loxosceles sp. & + & + & + & + & + & + & + \\
\hline Endecous sp. & + & + & + & + & + & + & + \\
\hline Trogiidae sp. 1 & + & + & + & + & - & + & + \\
\hline Trichodamon sp. & + & + & + & - & + & + & + \\
\hline Zelurus sp. & + & + & - & + & - & + & - \\
\hline Garypidae sp. 1 & + & + & + & - & + & - & - \\
\hline Venezillo sp. & - & - & + & + & + & & - \\
\hline
\end{tabular}

TABLE 5

Biological complexity index calculated for the caves in the study.

\begin{tabular}{|l|c|c|c|c|}
\hline \multicolumn{1}{|c|}{ Cave } & $\begin{array}{c}\text { Species richness } \\
\text { (except for } \\
\text { accidentals) }\end{array}$ & $\begin{array}{c}\text { Average width among } \\
\text { populational percentages }\end{array}$ & $\begin{array}{c}\text { Relative average } \\
\text { width (RAW) }\end{array}$ & $\begin{array}{c}\text { (Richness) }^{\mathbf{2}} \\
\text { RAW } \\
\text { (ICBC) }\end{array}$ \\
\hline Carlúcio & 15 & 10.00 & 21.43 & 10.50 \\
\hline Bonita & 14 & 28.58 & 44.45 & 4.41 \\
\hline Caboclo & 16 & 31.25 & 41.66 & 6.14 \\
\hline Ossos & 16 & 15.63 & 31.26 & 8.19 \\
\hline Brejal & 35 & 30.58 & 42.81 & 28.61 \\
\hline Janelão & 36 & 33.35 & 50.00 & 25.92 \\
\hline Rezar & 14 & 25.02 & 38.92 & 5.04 \\
\hline
\end{tabular}

The studied caves differed regarding to the actions of anthropic origin. Bonita cave was characterized by the high degree of "stepping", besides the uncountless pillagings found in espeleothems, facts that indicate an intense visitation in this cave.
Caboclo cave was also not very preserved, having spaces (near the entrance) that seem to have been used as a cattle shelter. The other caves were not intensively visited, except for the cave Janelão. In this cave, geological events were apparently 
more decisive in determining the communities' structure found nowadays.

\section{DISCUSSION}

The high richness variation found among the caves is certainly not just an effect of the different ability of resource caption in each system, but also of the degree of external climatic interference and anthropic use in each cave.

The caves crossed by the Peruaçu River presented a higher richness when compared to the dry caves, probably due to the larger importation of resources due to the presence of the river. In spite of the fact that the organic matter present in each cave was not quantified, it seems quite reasonable that Brejal and Janelão possess a higher resource importation than the other caves. Besides the presence of the large skylights, responsible for the contribution of great amounts of organic matter in those two systems, litter deposits submerged in several portions of the river were also observed inside those caves. The resource in the dry caves was constituted basically of guano piles, corpses, and vegetable material apported mainly by wind in the proximities of the entrances.

Studies accomplished by Chaimowicz (1984), Trajano (1992) and Gnaspini-Netto \& Trajano (1994) in the caves Janelão, Bonita and Caboclo indicated a species richness smaller than that found in the present work. However, the higher richness found in these caves during this study, that could be interpreted as an "increase" in the number of species, actually is just an effect of the distinct methodologies and sampling efforts employed by different authors. The data presented by those authors were not very homogeneous in systematic terms, and are only descriptive, without the quantification of the species (or morphospecies) populations, what makes them not effectively comparable with the data obtained in this study.

In qualitative terms, the genus and families more commonly found during the studies previously mentioned are the same found in this work (Loxosceles sp.; Endecous sp.; Noctuidae, Tineidae, Phoridae, Psychodidae etc.). This "qualitative" persistence of species or families cannot, however, be interpreted as the maintenance of the conservation of the area in the last decade. Since impacts are not appraised only by the disappearance of species, but many times by the decrease of their populations, it is impossible to classify the caves of the study as "conserved" just comparing the present data with data obtained in the last studies, which have not estimated, even grossly, the populations sizes.

The most widespread genera in the studied caves (Loxosceles sp. and Endecous sp.) are extremely common troglophiles in brazilian caves (Dessen et al., 1980; Trajano, 1987; Pinto-daRocha, 1995), fact that can explain their remarkable occurrence in the caves of the area.

Several other families as Noctuidae, Carabidae, Staphylinidae, Tenebrionidae, Chironomidae, Drosophilidae, Phoridae, Ceratopogonidae, Simulidae, Pholcidae, Armadilidae, Ctenidae, Phrynidae, Damonidae, Charontidae and Chernetidae, found in caves of Peruaçu valley, can be also found in caves placed in several other areas in Brazil (Trajano \& Gnaspini, 1991; Trajano \& Moreira, 1991; Berbert-Born \& Horta, 1995; Pinto-daRocha, 1995; Horta \& Moura, 1996; Ferreira \& Pompeu, 1997; Bichuette \& Santos, 1998; Dutra et al., 1998; Ferreira \& Martins, 1998; Ferreira \& Martins, 1999). This apparent similarity (at the family level) with cave invertebrate communities of other regions of Brazil can be due to the widespread distribution of these groups, generally preadapted to the cave environment.

The different patterns of species distribution inside the caves are due to the biology of each group. The genus Loxosceles and Endecous were the most well distributed inside the sampled caves. Since Loxosceles are spiders of high motility and low prey selectivity (Ferreira et al., in prep.), such distribution is supported by this and other works (Ferreira \& Martins, 1998; Dutra et al., 1998). The crickets Endecous sp., generalist detritivorous, were also well distributed inside some caves, probably due to its small diet specificity. Some morphospecies of certain families (Theridiidae, Dermestidae, Tenebrionidae, Tineidae, Armadillidae, and Trogiidae) were practically restricted to guano deposits, showing a clear preference for this substrata. Individuals of such families are commonly found in guano deposits in Brazilian caves (Ferreira \& Pompeu, 1997; Dutra et al., 1998; Ferreira, 1998; Ferreira \& Martins, 1998; Ferreira \& Martins, 1999), corroborating with data found in the present work. Amongst these, trogiids were 
relatively well distributed in some caves, populations having also been found associated to deposits of mocó (Kerodon rupestris) feces.

An interesting trait of the caves located in the area is the great number of "accidental" or "not very common" species, composing the cave communities. Individuals of families as Apidae, Pompilidae, Hesperiidae, Heliconiidae, and Anobiidae were frequently found in many studied caves (almost always in euphotic or disphotic areas). The presence of individuals from these groups indicate the degree of external interference in some caves, since a lot of species from these families would never survive in a "typical" cave system (with permanent lack of light and oligotrophic conditions).

The different fauna similarities found among the caves are probably due to two factors: geomorphology and distance among caves. Caves with similar geological structures tend to possess also similar resource "traps" (rivers, skylights etc.). These systems, even having different abilities for resources importation, should offer qualitatively similar resources (since these caves are under the same external domain), what can imply in the presence of the same type of organisms. This information corroborates the medium similarity found (0.423) between Janelão and Brejal (similar geological structures). By the other side, such caves presented, in general, low biological similarities with the other caves (with different geological structures).

The distance between caves is another explanation for the similarity values found. The higher similarity values were found among caves closely located, like Ossos, Carlúcio, and Caboclo, reaching 1.11 (between Ossos and Caboclo). In a general way, the varying similarity values found among the caves indicate a certain community heterogeneity, that can be due to some factors discussed below.

The use of the Biological Complexity Index is, actually, a first attempt to quantify the biological complexity in caves. So, the inclusion of several other parameters to make this index more robust and, consequently, more comparable among different caves is surely important.

The different biological complexity values found are probably an effect of the amount of resources and the degree of environmental oscillation in each system. Caves with a greater food suply can have a larger number of species, and, since certain conditions are maintained, such species will tend to be distributed in populations of different sizes. In this case, a system more complex than those in less rich caves with great populational disparities would be verified (as assumed in the index). Caves as Janelão (IBCC-25.92) and Brejal (IBCC-28.61) presented high IBCCs when compared to the other caves mainly due to their high species richness. It is important to stress that the numbers generated by this index are just a first "attempt" for the creation of a real robust number that can actually express the complexity of a cave system.

Many caves located in the Peruaçu River valley were disturbed, in some moment of their history, by natural phenomenons. The geological evolution of the carstic system, not parallelly followed by the biological evolution, certainly caused, in different moments, changes in the biological system. The opening of great skylights, as those found in Janelão, certainly modified the physical environment, probably modifying the communities' structure. Even not knowing the species composition of the communities present in Janelão before the opening of the skylights, we can make speculations based in the communities found in caves with more stable environments, as the Olhos D'água cave, located some kilometers from Janelão. In this cave, besides the great species richness, some troglobitic species can be found, as a fish (Trichomycterus itacarambiensis), opiliões (Iandumoema uai) and isopods (Chaimowicz, 1986). Obviously, we cannot assume the existence of troglobitic species in the past of Janelão for the simple proximity of caves in which they now exist, as Olhos D'água. However, we can admit the occurrence of a series of events that probably altered the biological system of this cave in some moment of its history.

Beyond those natural impacts in the "past" of some cave systems, other caves exhibit evident records of anthropic alterations. Bonita cave is a good example, possessing places with high stepping degree, certainly associated to the wide touristic visitation in this cave. Caboclo cave, besides presenting strong indications of constant visitation at the present time, shows clear signs of use by 
domestic animals. Such uses certainly are altering these cave communities; unfortunately it is not still known how and with which intensity. The high deforestation near the entrances of some caves is also a serious problem that deserves attention.

There are caves with different preservation degrees in the area, with invertebrate communities in varied complexity states. The communities of these caves undoubtedly deserve care, since the area is extremely important in the Brazilian biospeleological context. Such importance is not only denoted by the history of the area, but also by the almost unique geomorphological peculiarities that conditioned the harmonic coexistence of elements of epigean and hypogean systems in many caves present in the area.

Acknowledgments - Raquel T. de Moura, Maria Elina Bichuette, Frederico Lott, Leandro Jonathas, Hayato and Vítor Moura helped in the field. Flávio Túlio helped in the laboratory work. We also thank Dr. Rogério Parentoni Martins for the helpfull comments. The FNMA (Fundo Nacional do Meio Ambiente) provided logistic support. This is a contribution of the Program in Ecology and Wildlife Management of the Universidade Federal de Minas Gerais, Belo Horizonte, Brazil, and of the Bambuí group of speleological research.

\section{REFERENCES}

BERBERT-BORN, M. L. \& HORTA, L. S., 1995, Espeleologia. In: Projeto mapas municipais, município de Morro do Chapéu. CPRM, Salvador, Cap. 15.

BICHUETTE, M. E. \& SANTOS, F. H. S., 1998, Levantamento e dados ecológicos da fauna de invertebrados da Gruta dos Paiva, Iporanga, SP. O Carste, 10(1): 14-19.

CHAIMOWICZ, F., 1984, Levantamento bioespeleológico em algumas grutas de Minas Gerais. Espeleo-tema, 14: 97-107.

CHAIMOWICZ, F., 1986, Observações preliminares sobre o ecossistema da Gruta Olhos d'Água, Itacarambi, MG. Espeleo-tema, 15: 65-77.

CULVER, D. C., 1982, Cave Life. Evolution and Ecology. Harvard University Press. Cambridge, Massachussets and London, England, 189p.

DESSEN, E. M. B., ESTON, V. R., SILVA, M. S., TEMPERINI-BECK, M. T. \& TRAJANO, E., 1980, Levantamento preliminar da fauna de cavernas de algumas regiões do Brasil. Ciência e Cultura, 32(6): 714-725.

DUTRA, G. M., HORTA, L. S., BERBERT-BORN, M. L., 1998, Levantamento Espeleológico. In: APA Carste de Lagoa Santa: patrimônio espeleológico, histórico e cultural. CPRM/IBAMA, BH, vol. 3.
ELLIOT, W. R., 1981, Damming up the caves. Caving International, 10: 38-41.

FERREIRA, R. L. \& POMPEU, P. S., 1997, Fatores que influenciam a riqueza e a diversidade da fauna associada a depósitos de guano na Gruta Taboa, Sete Lagoas, Minas Gerais, Brasil. O Carste, 2(9): 30-33.

FERREIRA, R. L., 1998, Ecologia de comunidades cavernícolas associadas a depósitos de guano de morcegos. Dissertação de Mestrado, UFMG, Belo Horizonte, 85p.

FERREIRA, R. L. \& MARTINS, R. P., 1999, Guano de morcegos: fonte de vida em cavernas. Ciência Hoje, 25(146): 34-40.

FERREIRA, R. L. \& MARTINS, R. P., 1998, Diversity and distribution of spider associated with bat guano piles in Morrinho Cave (Bahia State, Brazil). Diversiy and Distributions, 4: 235-241.

GNASPINI-NETTO, P. \& TRAJANO, E., 1994, Brazilian cave invertebrates, with a checklist of troglomorphic taxa. Revta. Bras. Ent., 38(34): 549-584.

HERRERA, F. F., 1995, Las comunidades de artropodos del guano del guácharos en la cueva del guácharo, Venezuela. Bol. Soc. Venez. Espeleol., 29: 39-46.

HOLSINGER, R. \& CULVER, D. C., 1988, The Invertebrate Cave Fauna of Virginia and a Part of Eastern Tennessee: Zoogeography and Ecology. Brimleyana, 14: 1-162.

HORTA, L. S. \& MOURA, R. T., 1996, Bioespeleologia. In: Expedições espeleológicas franco-brasileiras, Goiás 94 e 95. GBPE/GREGEO/GSBM, Brasília, pp. 58-63.

IBGE - Fundação Instituto Brasileiro de Geografia e Estatística, 1993, Mapa de Vegetação do Brasil. Rio de Janeiro.

LEWIS, J. J., 1982, Aquatic ecosystems and management problems in the Mammoth cave area. In: R. C. Wilson \& J. J. Lewis (eds.), National Cave Management Symposia Proceedings. Carlsbad, New Mexico 1978 and Mammoth Cave, Kentucky 1980. Pygmy Dwarf Press, Oregon City, Oregon, pp. 73-76.

LISOWSKI, E. A. \& POULSON, T. L., 1981, Impacts of lock and Dam Six on baselevel ecosystem in Mammoth Cave. In: T. L. POULSON, (ed.), Cave Research Foudation 1979 Annual Report. Adobe Press, Albuquerque, New Mexico, pp. 48-54.

PILÓ, L. B., 1997, Caracterização regional do carste do vale do rio Peruaçu. O Casrte, 9(2): 22-29.

PINTO-DA-ROCHA, R., 1995, Sinopse da fauna cavernícola do Brasil (1907-1994). Papéis Avulsos de Zoologia, $39(6), 61-163$.

POULSON, T. L. \& WHITE, W. B., 1969, The cave environment. Science, 165: 971-981.

TRAJANO, E., 1987, Fauna cavernícola brasileira: composição e caracterização preliminar. Rev. Bras. Zool., 3(8): 533-561. 
TRAJANO, E., 1992, Nota sobre os cavernícolas da Província Espeleológica do Bambuí. Espeleo-Tema, 16: 95-101.

TRAJANO, E. \& GNASPINI-NETTO, P., 1991, Composição da fauna cavernícola brasileira, com uma análise preliminar da distribuição dos táxons. Revta. Bras. Zool., 7: 383-407.
TRAJANO, E. \& MOREIRA, J. R. A., 1991, Estudo da fauna de cavernas da província espeleológica arenítica Altamira-Itaituba, Pará. Rev. Brasil. Biol., 51(1), 13-29.

WOLDA, H., 1981, Similarity indices, sample size and diversity. Oecologia, 50: 296-302. 